\title{
Effects of hook size on the catches of undersized snapper Pagrus auratus
}

\author{
N. M. Otway, J. R. Craig \\ Fisheries Research Institute, PO Box 21, Cronulla, New South Wales 2230, Australia
}

\begin{abstract}
Demersal longlines baited with uniformly-sized pieces of squid were used to test the selective nature of 3 'Mustad' tuna hooks (\#12, \#10 and \#8) on the catches of undersized and legal-sized snapper Pagrus auratus. Increasing the absolute size of the hook by $26.5 \%$ (i.e. \#12 to \#10) resulted in significantly fewer snapper under the legal size $(250 \mathrm{~mm}$ fork length) being caught. Increasing the absolute size of the hook by $64 \%$ (i.e. \#12 to \#8) did not result in a further decrease in the number of undersized snapper caught but, it did result in significantly larger individuals being caught on the \#8 hook. These results indicate that predictions of hook-selectivity based on the normal and logistic curves are not directly applicable. An examination of other hook dimensions showed that the length of the bill was inversely correlated with the number of under legal-size snapper. These results suggest that other hook dimensions warrant further investigation.
\end{abstract}

\section{INTRODUCTION}

There is a substantial literature on the methods for evaluating the selective properties of trawl and gillnets (e.g. Gulland 1969, Hamley 1975, Pope et al. 1975, Tokai \& Kitahara 1988, Boy \& Crivelli 1989) and this has led to much research in this area (e.g. Borgstrom 1989, Tokai et al. 1989, and for tangle nets see Kennelly \& Craig 1989). Unfortunately, the same cannot be said for the selective properties of hooks (Saetersdal 1963, Ralston 1982) in spite of the numerous fisheries that rely on hooks as the means of capture. Results of the few studies that have been done are variable, often contradictory, and thus generalisations concerning hook selectivity cannot be substantiated at this time.

The effects of hook selection may be obvious and occur directly through the capture of fish under the minimum legal length. Alternatively, there may be indirect effects arising from the bias of demographic data which form the basis for management of fisheries. For example, hook selectivity generally results in biased size-frequency data (Ralston 1982) and thus, any estimates of growth and mortality derived from such data may also be biased and potentially misleading. Hook selectivity may also influence the strategies adopted for the management of 'hook-based' fisheries, especially where minimum legal size regulations are imposed. Consequently, it is essential that studies of hook selectivity be incorporated into demographic studies of 'hook-based' fisheries.

Studies that have demonstrated hook selectivity (e.g. Saetersdal 1963, Koike et al. 1968, Kanda et al. 1978) have done so by varying the size of hooks by 76 to $215 \%$. The effects obtained were manifest in different ways. Several researchers have shown that varying hook size alters the minimum size of capture and not the capture of large fish. For example, McCracken (1963) and Saetersdal (1963) have both shown that the sizes at first capture of Atlantic cod Gadus morhua and haddock Melanogrammus aeglefinus were increased by using larger hooks. Other authors (e.g. Fry 1949, Fraser 1955) have concluded that selection by hooks is extremely pronounced, but dependent on the sizestructure of the population.

A number of investigators have shown that varying the size of hooks has no effect. For example, in a study of several species of lutjanid Ralston (1982) showed that increasing the size of hooks by $71 \%$ had no effect on the size of fish nor on the numbers caught. He also 
concluded that the variation in the catch among sites and days far exceeded any effect that could be attributable to differing hook sizes. Bertrand (1988) also drew a similar conclusion after studying the handline fishery of the Saya de Malha banks in the Indian Ocean.

In this paper we document the results of an experiment examining the effects of different-sized hooks on catches of the commercially and recreationally important snapper Pagrus auratus (Bloch \& Schneider, 1801). This species is fished commercially off the coast of New South Wales (Australia) using demersal longlines, trawls, traps and handlines (McDonall 1982, Kennelly unpubl.). This species is, like many of the commercially and recreationally important fish caught off New South Wales, subject to a minimum legal size regulation (Anon. 1991). At present, the minimum legal length has been set at a fork-length (FL) of $250 \mathrm{~mm}$.

Traditionally the absolute size of a hook has been calculated as the product of its length and width (e.g. Saetersdal 1963, Kanda et al. 1978, Ralston 1982). These values have then been used to estimate the relative differences among hooks of varying sizes (e.g. Bertrand 1988, Ralston 1990). The use of measurements of the gape or weight of a hook, for example, may also be equally valid, but do not appear to have been considered to date. It is possible that these alternatives could prove to be more useful, in that they might assist in identifying the attributes of hooks to which the fish respond. Consequently, we also consider a range of alternative hook dimensions and examine their relationships with hook size and selectivity.

\section{MATERIALS AND METHODS}

Field sampling. The experiment was conducted in the coastal waters off Sydney (Australia) between Long Reef and Marley Beach and formed part of a larger study documenting the distribution and abundance of demersal fish in this region. Up to 18 locations within this region were sampled every 3 mo from winter 1989 to autumn 1990 using demersal longlines. This sampling technique enabled the relative abundances to be estimated and a simultaneous examination of the selective properties of hooks of differing sizes. Using longlines also overcomes biases associated with the skills of different fishermen when handlining is used (see Ralston 1982, Bertrand 1988). The selectivities of 3 sizes of 'Mustad' tuna hooks (\#12, \#10 \& \#8; Fig. 1) were examined in this experiment. The demersal longlines were of similar construction to the bottom-set longlines of Russell et al. (1988). Briefly, each longline consisted of a $76 \mathrm{~m}$ negatively buoyant, ground-line ( $5 \mathrm{~mm}$ hard-laid polypropylene rope) weighted at both ends; a 90 to $120 \mathrm{~m}$ buoy-line $6 \mathrm{~mm}$ polyethylene
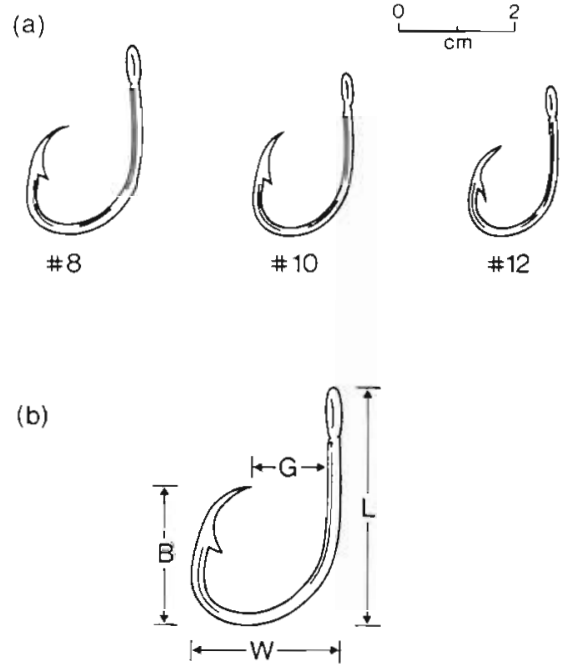

Fig. 1. Diagram of (a) the \#12, \#10 and \#8 'Mustad' tuna hooks used, and (b) the other hook dimensions examined in the study. L: maximum length; $W$ : maximum width; $B$ : length of bill; $G$ : gape

rope); and a danbuoy with additional floats. Thirtythree hooks, attached to $50 \mathrm{~cm}$ snoods of $25 \mathrm{~kg}$ breaking-strain monofilament line, were clipped onto the ground-line with shark-clips when the lines were set. All the hooks were baited with uniformly-sized pieces of squid (see Ralston 1982, 1990) ensuring that the hook-size was independent of the size of the bait. The baited hooks were then stored in a freezer until required.

Twelve replicate longlines ( $\mathrm{n}=396$ hooks in total) were set approximately parallel to the shore at each location. When setting the lines, 11 groups of 3 hooks, each group comprising a \#12,\#10 and \#8 hook, were clipped onto each ground-line allowing a $2 \mathrm{~m}$ interval between each snood. The order of the \#12, \#10 and \#8 hooks within each group was determined at random. All longlines were allowed to fish for $2.5 \mathrm{~h}$, on average, prior to hauling. The fork lengths of all Pagrus auratus were measured to the nearest $\mathrm{mm}$ and the hook-size recorded. The number of baits lost per longline was also noted.

Hook dimensions. The length, width, gape, guage and length of the bill of the 3 hooks (Fig. 1) were quantified by measuring 5 sets of 5 randomly-chosen hooks of each size to the nearest $0.01 \mathrm{~mm}$ with calipers. The absolute size (sensu Ralston 1982) of each of the 3 hooks was also calculated in the traditional manner, i.e. as the product of a hook's length and width. The weights of the $\# 12, \# 10$ and $\# 8$ hooks were also estimated to the nearest $\mathrm{mg}$ using an additional 5 randomly-chosen hooks of each size.

Statistical analyses. Most of the data were analysed by analyses of variance after preliminary tests for ho- 
Table 1. Summary of analyses of the hook dimensions for the \#12, \#10, and \#8 'Mustad' tuna hooks. Analyses of variance compare differences among hook dimensions: $n=5$, Cochran's test not significant $(p>0.05)$ in all analyses, $S N K$-tests $(p=0.05)$ for comparisons a mong means

\begin{tabular}{|c|c|c|c|c|c|c|c|c|c|}
\hline Hook dimension & $\begin{array}{l}\text { Hook } \\
\text { size }\end{array}$ & Mean & $\mathrm{SE}$ & $\begin{array}{l}\text { Percent } \\
\text { increase } \\
\text { in size }\end{array}$ & $\begin{array}{l}\text { Source of } \\
\text { variation }\end{array}$ & $\begin{array}{r}\text { ses } \\
\text { df }\end{array}$ & $\begin{array}{c}\text { variance } \\
\text { MS }\end{array}$ & $F$ & $\begin{array}{l}\text { Results of } \\
\text { SNK-test }\end{array}$ \\
\hline Absolute size $\left(\mathrm{mm}^{2}\right)$ & $\begin{array}{r}12 \\
10 \\
8\end{array}$ & $\begin{array}{l}404.4 \\
511.5 \\
663.0\end{array}$ & $\begin{array}{l}7.39 \\
6.53 \\
3.29\end{array}$ & $\begin{array}{c}- \\
26.5 \\
64.0\end{array}$ & $\begin{array}{l}\text { Hook size } \\
\text { Residual } \\
\text { Total }\end{array}$ & $\begin{array}{r}2 \\
12 \\
14\end{array}$ & $\begin{array}{r}84410 \\
8\end{array}$ & $1055^{\cdots}$ & $12<10<8$ \\
\hline Length $(\mathrm{mm})$ & $\begin{array}{r}12 \\
10 \\
8\end{array}$ & $\begin{array}{l}25.68 \\
28.40 \\
32.53\end{array}$ & $\begin{array}{l}0.32 \\
0.14 \\
0.16\end{array}$ & $\begin{array}{c}- \\
10.6 \\
26.6\end{array}$ & $\begin{array}{l}\text { Hook size } \\
\text { Residual } \\
\text { Total }\end{array}$ & $\begin{array}{r}2 \\
12 \\
14\end{array}$ & $\begin{array}{r}59.38 \\
0.26\end{array}$ & $228^{\cdots}$ & $12<10<8$ \\
\hline Width $(\mathrm{mm})$ & $\begin{array}{r}12 \\
10 \\
8\end{array}$ & $\begin{array}{l}15.74 \\
18.01 \\
20.38\end{array}$ & $\begin{array}{l}0.25 \\
0.17 \\
0.09\end{array}$ & $\begin{array}{c}- \\
14.4 \\
29.5\end{array}$ & $\begin{array}{l}\text { Hook size } \\
\text { Residual } \\
\text { Total }\end{array}$ & $\begin{array}{r}2 \\
12 \\
14\end{array}$ & $\begin{array}{r}26.90 \\
0.17\end{array}$ & $158^{\circ}$ & $12<10<8$ \\
\hline Bill (mm) & $\begin{array}{r}12 \\
10 \\
8\end{array}$ & $\begin{array}{l}13.55 \\
16.51 \\
17.18\end{array}$ & $\begin{array}{l}0.22 \\
0.64 \\
0.31\end{array}$ & $\begin{array}{c}- \\
21.9 \\
26.8\end{array}$ & $\begin{array}{l}\text { Hook size } \\
\text { Residual } \\
\text { Total }\end{array}$ & $\begin{array}{r}2 \\
12 \\
14\end{array}$ & $\begin{array}{r}18.70 \\
0.92\end{array}$ & $20.3^{*}$ & $12<10=8$ \\
\hline Gape (man) & $\begin{array}{r}12 \\
10 \\
8\end{array}$ & $\begin{array}{r}8.17 \\
9.34 \\
10.13\end{array}$ & $\begin{array}{l}0.20 \\
0.17 \\
0.12\end{array}$ & $\begin{array}{c}- \\
14.3 \\
23.9\end{array}$ & $\begin{array}{l}\text { Hook size } \\
\text { Residual } \\
\text { Total }\end{array}$ & $\begin{array}{r}2 \\
12 \\
14\end{array}$ & $\begin{array}{l}4.84 \\
0.14\end{array}$ & $34.6^{\cdots}$ & $12<10<8$ \\
\hline Guage (mm) & $\begin{array}{r}12 \\
10 \\
8\end{array}$ & $\begin{array}{l}1.69 \\
1.92 \\
2.14\end{array}$ & $\begin{array}{l}0.02 \\
0.01 \\
0.01\end{array}$ & $\begin{array}{c}- \\
14.0 \\
26.5\end{array}$ & $\begin{array}{l}\text { Hook size } \\
\text { Residual } \\
\text { Total }\end{array}$ & $\begin{array}{r}2 \\
12 \\
14\end{array}$ & $\begin{array}{l}0.251 \\
0.001\end{array}$ & $251^{\cdots}$ & $12<10<8$ \\
\hline Weight (mg) & $\begin{array}{r}12 \\
10 \\
8\end{array}$ & $\begin{array}{r}946 \\
1318 \\
1902\end{array}$ & $\begin{array}{l}51 \\
37 \\
20\end{array}$ & $\begin{array}{r}-- \\
39.3 \\
101.0\end{array}$ & $\begin{array}{l}\text { Hook size } \\
\text { Residual } \\
\text { Total }\end{array}$ & $\begin{array}{r}2 \\
12 \\
14\end{array}$ & $\begin{array}{r}116100 \\
7\end{array}$ & $16586^{\cdots}$ & $12<10<8$ \\
\hline
\end{tabular}

mogeneity of variances (Cochran's test, Winer 1971). When variances were heterogeneous, data were transformed using the procedures outlined in Winer (1971) and Underwood (1981). Following analysis of variance, multiple comparisons among means were done using Student-Newman-Keuls (SNK) tests (Snedecor \& Cochran 1980).

\section{RESULTS}

\section{Hook dimensions}

The relative differences in absolute hook size increased from $26.5 \%$ when comparing the \#12 and \#10 hooks to $64.0 \%$ when the $\# 12$ and \#8 hooks were compared. The relative differences in size for the lengths, widths, gapes, guages and weights of the 3 hooks differed from that of the absolute size (Table 1), but this was not unexpected. All of these variables, except the length of the bill, showed a trend with increasing hook size that was similar to absolute size. The relative differences in the length of the bill of the 3 hooks differed from those of the other variables in that there was a marked increase in the relative difference between the
\#12 and \#10 hooks, and this was followed by a small (not statistically significant) increase between the \#10 and \#8 hooks (Table 1).

The analyses of the absolute sizes, lengths, widths, gapes, guages and weights of the 3 hooks showed similar results. The \#12 hook was always significantly smaller than the \#10 hook, and both were always significantly smaller than the \#8 hook (Table 1; analyses of variance and SNK-tests of means, $p<0.05$ ). The length of the bill proved to be an exception to the above result in that the bill of the \#12 hook was significantly shorter than the bills of the $\# 10$ and $\# 8$ hooks which did not differ from each other (Table 1; analysis of variance and SNK-test of means, $p<0.05$ ).

\section{Number of fish}

It was not possible to incorporate locations in the analyses because of substantial variability in the number of Pagrus auratus caught among times and locations. Consequently, analyses of the number of snapper caught on the different hooks were done by pooling across locations within the sampling region and using times as replicates. It was possible, however, 

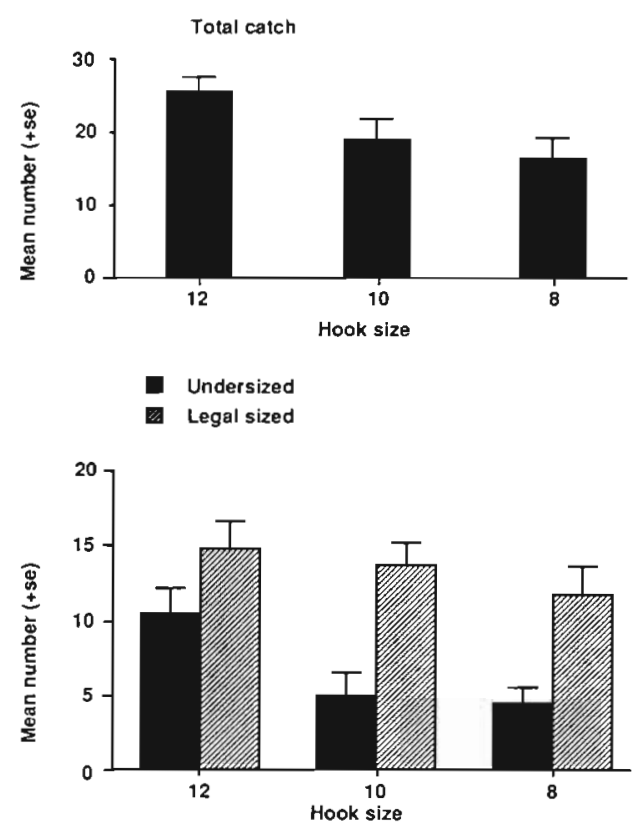

Fig. 2. Pagrus auratus. Mean (+ SE) number of snapper of all sizes, $<250 \mathrm{~mm}$ and $\geq 250 \mathrm{~mm}$ caught on $\# 12$, \#10 and \#8 'Mustad' tuna hooks. Note that $250 \mathrm{~mm}$ is the minimum legal fork length for $P$. auratus in the waters of New South Wales

to include 'Times' as a factor in the analyses of the size of $P$. auratus caught on the \#12, \#10 and \#8 hooks, but this still required the pooling of data across locations.

A total of 241 snapper was caught over the 4 sampling periods and the mean numbers caught on the

Table 2. Pagrus auratus. Analyses of the total number, and numbers of illegal-and legal-sized snapper caught on the $\# 12$, \#10 and \#8 'Mustad' tuna hooks. Analyses of variance of data pooled across locations; ns: not significant $p>0.05$; - significant $p<0.05$. Results of SNK-tests; horizontal lines underlie hook sizes not significantly different at $p=0.05$

\begin{tabular}{|c|c|c|c|c|c|c|c|c|}
\hline \multirow{3}{*}{\multicolumn{2}{|c|}{$\begin{array}{l}\text { ANOVA } \\
\text { Source of df } \\
\text { variation }\end{array}$}} & \multicolumn{7}{|c|}{ Type of individuals } \\
\hline & & \multicolumn{2}{|r|}{ All } & & \multicolumn{2}{|c|}{ Illegal $^{\alpha}$} & \multicolumn{2}{|c|}{ Legal $^{\mathrm{b}}$} \\
\hline & & MS & $F$ & & MS & $F$ & MS & $F$ \\
\hline Hook size & & 86.33 & 33.40 & ns & 44.33 & $5.25^{\circ}$ & 9.33 & $0.76 \mathrm{~ns}$ \\
\hline Residual & 9 & 25.36 & & & 8.44 & & 12.25 & \\
\hline Total & 11 & & & & & & & \\
\hline \multicolumn{9}{|l|}{ SNK-tests } \\
\hline \multicolumn{3}{|c|}{ Type of individuals } & \multicolumn{3}{|c|}{ Hook size } & & & \\
\hline All & & & 12 & 10 & 8 & & & \\
\hline Illegal & & & 12 & 10 & 8 & & & \\
\hline Legal & & & 12 & 10 & 8 & & & \\
\hline
\end{tabular}
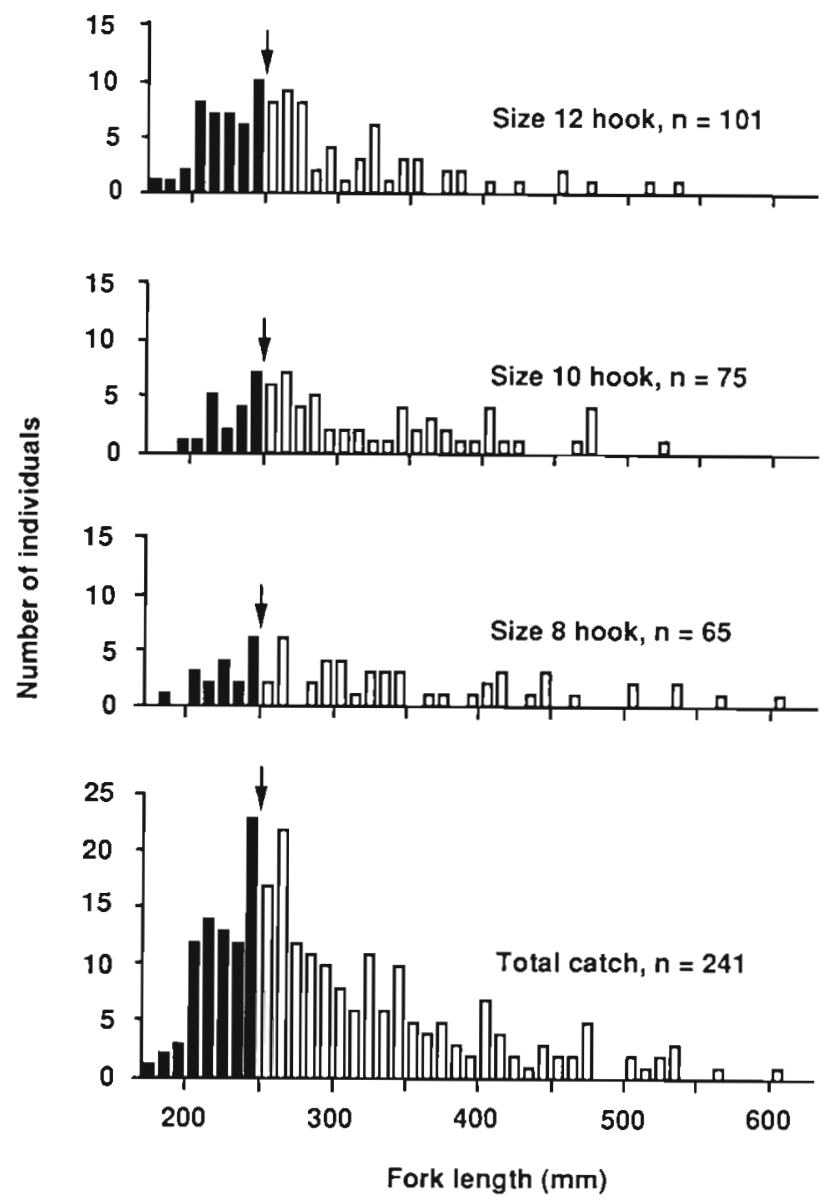

Fig. 3. Pagrus auratus. Length-frequency distributions of snapper caught on \#12, \#10 and \#8 'Mustad' tuna hooks. Arrow indicates the minimum legal fork length of $250 \mathrm{~mm}$ solid bars are undersized fish

\#12, \#10 and \#8 hooks were not significantly different (Fig. 2 and Table 2; analysis of variance, $p>0.05$ ). There was, however, a trend towards smaller catches as the hook size increased (Fig. 2). Over the 4 sampling periods the \#12 hook caught 101 snapper and of these, $42 \%$ were under the minimum legal size of $250 \mathrm{~mm}$ FL (Fig. 3). By comparison, only 27 and $28 \%$ of the snapper caught on the \#10 and \#8 hooks, respectively, were under the minimum legal size (Fig. 3). More detailed analysis of the numbers of snapper under the minimum legal size showed that significantly more undersized snapper were caught on the \#12 hook compared to the \#10 and \#8 hooks, which did not differ (Table 2; analysis of variance and SNK-test of means in Fig. 2, $p<0.05)$. Comparisons of the legal-sized snapper ( $\geq 250 \mathrm{~mm} \mathrm{FL)} \mathrm{indicated} \mathrm{that} \mathrm{the} \mathrm{mean} \mathrm{numbers} \mathrm{caught}$ on the 3 hook sizes were not significantly different (Table 2; analysis of variance, $p>0.05$ ), although there was a slight trend towards smaller catches as the hook size increased (Fig. 2). 


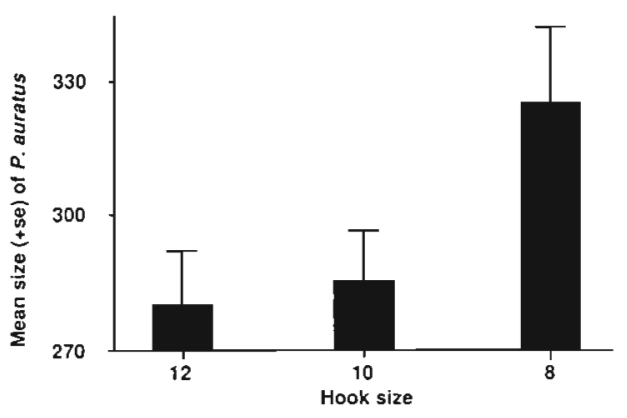

Fig. 4. Pagrus auratus. Mean (+ SE) fork length of snapper caught on the \#12, \#10 and \#8 'Mustad' tuna hooks

\section{Size of fish}

The size ranges of snapper caught by the 3 hook sizes were similar when the data were pooled across the 4 sampling periods (Fig. 3). The mean (SE) lengths of snapper caught on the \#12,\#10 and \#8 hooks as calculated from the length-frequency distributions (Fig. 3) were $277.3(7.1) \mathrm{mm}, 305.8$ (9.1) $\mathrm{mm}$ and 323.2 (12.2) $\mathrm{mm}$, respectively. This suggested that the hook size also affected the mean size of the snapper caught. This was investigated further by comparing the lengths of fish caught on each of the 3 hook sizes and in each of the 4 sampling periods. The comparison was based on a balanced analysis of variance using the fork lengths of 11 individuals selected at random from the total number of fish caught in each hook size/sampling period combination. This analysis showed that the \#8 hook caught significantly larger fish compared to those on the \#10 and \#12 hooks which did not differ (Table 3 ; analysis of variance and SNK-test of means in Fig. 4, $\mathrm{p}<0.05$ ). Furthermore, it is important to note that this result was consistent through time as no other sources of variation were significant (Table 3 ).

Table 3. Pagrus auratus. Analysis of the mean fork-length of snapper caught on \#12, \#10 and \#8 'Mustad' tuna hooks. Analysis of variance of data pooled across locations; ns; not significant $p>0.05$; significant $p<0.05$. Results of SNKtests; horizontal lines underlie hook size not significantly different at $\mathrm{p}=0.05$

\begin{tabular}{|lrrr|}
\hline $\begin{array}{lrrr}\text { ANOVA } \\
\text { Source of variation }\end{array}$ & df & MS & $F$ \\
\hline Hook size & 2 & 24470 & $3.37^{\circ}$ \\
Season & 3 & 499 & $0.07 \mathrm{~ns}$ \\
Hook size $\times$ season & 6 & 12550 & $1.72 \mathrm{~ns}$ \\
Residual & 120 & 7260 & \\
Total & 131 & & \\
SNK-tests & & & \\
Hook size & $10 \quad 8$ & \\
& \multicolumn{2}{|r}{} \\
\hline
\end{tabular}

\section{Loss of baits}

As Ralston (1982) has pointed out, the retention of baits on hooks of different sizes may also provide another means of estimating selection. Estimates obtained in this manner are, however, dependent on a number of untested assumptions. For example, it is necessary to assume that strike rate is not affected by hooks of differing sizes (Ralston 1982). With this in mind, the analysis of baits lost indicated that the number lost per line did not vary among times and locations within the sampling region (analysis of variance, $p>0.05$ ). More importantly, the number of baits lost on \#12, \#10 and \#8 hooks showed no consistent differences.

\section{DISCUSSION}

This experiment has shown that catches of Pagrus auratus can be significantly modified by using hooks of different sizes. These modifications were evident through changes in the numbers and sizes of fish caught. Varying the hook sizes did not significantly affect the number of legal-sized $P$. auratus caught during the study. In contrast, smaller numbers of undersized fish were caught on the larger hooks (\#10 \& \#8) when compared to the smallest hook (\#12) and this occurred in response to a $26.5 \%$ increase in the absolute hooksize. Increasing the hook size by $64 \%$ (i.e. \#12 to \#8 hook) did not elicit a further decrease in the number of undersized snapper caught. However, the $64 \%$ increase in absolute hook size resulted in a substantial increase in the mean size of snapper.

This demonstration of hook selection with only 26.5 and $64 \%$ increases in absolute hook size is quite remarkable given that the smallest, previously reported increase in absolute hook size responsible for changes in selective characteristics of hooks was $76 \%$ (Saetersdal 1963). Other studies (e.g. Koike et al. 1968, Kanda et al. 1978) have reported changes to the sizestructure of the target populations, but only after increasing the hook sizes by 215 and $111 \%$, respectively. The failure to identify hook selectivity in some studies may be the result of poor experimental design. For example, the experiment used by Bertrand (1988) confounded different hook sizes with baits of different sizes. Comparisons of data for hooks of different sizes (\#5 vs \#8 and \#5 vs \#7) yielded contradictory results and these led Bertrand to conclude that there was no evidence for hook selectivity. Previous studies (e.g. Allen 1963, McCracken 1963) have already shown that bait size can influence the size of fish caught and potentially mask the effects of hook size. Had Bertrand eliminated the confounding effect of differing bait 
sizes in the comparison between $\# 5$ and \#8 hooks, he may well have drawn different conclusions.

Estimates of the selectivity of gill-nets and trawl-nets have been based on the properties of the normal and logistic distributions, respectively (Hamley 1975, Pope et al. 1975). It is not clear whether either distribution is applicable to the selectivity of hooks. The results of at least 1 study (Ralston 1990) suggest that neither distribution is directly applicable. His research showed that small hooks caught substantially more small fish compared to the large hooks which tended to be more effective at capturing larger fish. Our results for Pagrus auratus are in line with those of Ralston (1990), in that the smallest (\#12) hook caught significantly more small snapper and the largest hook (\#8) caught significantly larger individuals. Consequently, our results also suggest that neither model in its simplest form can predict the hook selectivity of $P$. auratus with great certainty.

Whilst most authors have concentrated on the absolute size as a measure of the differences among hooks (e.g. Saetersdal 1963, Koike et al. 1968, Kanda et al. 1978, RaIston 1982), the use of the other dimensions examined in this study may be equally valid and possibly more applicable given the many different shapes, weights, etc. of hooks. The length of the bill may actually prove to be a more useful measure given the results of this study. For example, the length of the bill was inversely correlated with the number of undersized snapper caught on hooks of increasing size. We recommend that future studies also examine the relationships between alternative hook dimensions and selectivity.

This study has identified an avenue of research that has implications for the management of this species as the $26.5 \%$ increase in hook size resulted in a $50 \%$ reduction in the number of undersized fish caught and no significant decline in the number of legal-sized fish caught. Furthermore, the use of the \#8 hook $164 \%$ increase in hook-size) resulted in the capture of significantly larger snapper. It is important to note, however, that increasing the hook size did not completely eliminate the capture of undersized fish and consequently, there is an obvious need for more research in this area.

Finally, whilst we agree with Ralston (1990) that our understanding of hook selectivity is at best rudimentary, we also feel that studies in this area will only progress (sensu Kuhn 1970) if care is given to experimental design (for further discussion see Cox 1958, Pope 1963, Green 1979). To this end, we should increase our understanding of the logic of ecological experiments, define precisely the hypotheses under contention, and ensure that appropriate experimental tests are done (Underwood 1990). It is essential that future experiments address hypotheses associated with baits of different sizes, composition and/or texture, hooks of varying sizes and shapes, and all the associated interactions. Experiments incorporating these additional factors should identify appropriate strategies for reducing the numbers of undersized snapper caught. These experiments would also need to be done at several sites and repeated through time to quantify further, the degree of spatial and temporal variation in hook-selectivity. Only by such experiments can the potential biases in demographic studies be identified and the appropriate management procedures for 'hookbased' fisheries be determined.

Acknowledgements. This study was funded by the Sydney Water Board and the State Pollution Control Commission as part of the Deepwater Ocean Outfalls Environmental Monitoring Progranme. We thank P. Fagan and G. Henry for helpful discussions. We are grateful to our colleagues in the Institute's Deepwater Ocean Outfalls Monitoring (DOOM) lab for their unrelenting efforts. N.M.O. also thanks S. Otway for stimulating discussions on many aspects of this work. The comments of J. Bell, D. Ferrell, C. Gray and R. Kearney were constructive and improved the manuscript.

\section{LITERATURE CITED}

Allen, K. R. (1963). The influence of behaviour on the capture of fish with baits. In. The selectivity of fishing gear. Spec. Publ. No. 5. Int. Comm. Northwest Atl. Fish., Dartmouth, N.S., Canada, p. 5-7

Anonymous. (1991). The saltwater guide - the angler's guide to saltwater fishing laws, 4 th edn. New Wales Fisheries, Sydney

Bertrand, J. (1988). Selectivity of hooks in the handline fishery of the Saya de Malha banks (Indian Ocean). Fish. Res. 6 : $249-255$

Borgstrom, R. (1989). Direct estimation of gill-net selectivity for roach (Rutilus rutilus (L.)) in a small lake. Fish. Res. 7 $289-298$

Boy, V., Crivelli, A. J. (1989). Simultaneous determination of gillnet selectivity and population age-class distribution for two cyprinids. Fish. Res. 6: $337-345$

Cox, D. R. (1958). Planning of experiments. John Wiley \& Sons, New York

Fraser, J. M. (1955). The smallmouth bass fishery of South Bay, Lake Huron. J. Fish. Res. Bd Can. 12: 147-177

Fry, F. E. J. (1949). Statistics of a lake trout fishery. Biometrics 5: $27-67$

Green, R. (1979). Sampling design and statistical methods for environmental biologists. John Wiley \& Sons, New York

Gulland, J. A. (1969). Manual of methods for fish stock assessment. Part I. Fish population analysis. FAO Man. Fish. Sci. 4: $1-154$

Hamley, J. M. (1975). Review of gillnet selectivity. J. Fish. Res Bd Can. 32: 1943-1969

Kanda, K. Koike, A., Takeuchi, S., Ogura, M. (1978) Selectivity of the hook for mackerel, Scomber japonicus Houttuyn, pole fishing. J. Tokyo Univ. Fish. 64: 115-123

Kennelly, S. J., Craig, J. S. (1989). Effects of trap design, independence of traps and bait on sampling populations of spanner crabs Ranina ranina. Mar. Ecol. Prog. Ser 51. 49-56

Koike, A., Takeuchi, S., Ogura, M., Kanda, K., Arihara, C. 
(1968). Selection curve of the hook of long line. J. Tokyo Univ. Fish. 55: 77-82

Kuhn, $T$ (1970). The structure of scientific revolutions, 2nd edn. Univ. of Chicago Press, Chicago

McCracken, F. D. (1963). Selection by codend meshes and hooks on cod, haddock, flatfish and redfish. In: The selectivity of fishing gear. Spec. Publ. No. 5. Int. Comm Northwest Atl. Fish., Dartmouth, N.S., Canada, p. 131-155

McDonall, V. C. (1982). Commercial fisheries of New South Wales. NSW State Fisheries Publication, Sydney, p. 1-66

Pope, J. A. (1963). A note on experimental design. In: The selectivity of fishing gear Spec. Publ. No. 5. Int. Comm. Northwest Atl. Fish., Dartmouth, N.S., Canada, p. $175-179$

Pope, J. A., Margetts, A. R., Hamley, J. M., Akyuz. (1975). Manual of methods for fish stock assessment. Part III. Selectivity of fishing gear. FAO Fish. Tech. Pap. No. 41 (Rev. 1): 1-46

Ralston, S. (1982). Influence of hook size in the Hawaiian deep-sea handline fishery. Can. J. Fish. Aquat. Sci. 39: $1297-1302$

Ralston, S. (1990). Size selection of snappers (Lutjanidae) by hook and line gear Can. J. Fish. Aquat. Sci. 47: 696-700

Russell, G. M., Gutherez, E. J., Barans, C. A. (1988).
Evaluation of demersal longline gear off South Carolina and Puerto Rico with emphasis on deep-water reef stocks. Mar. Fish. Rev. 50: 26-31

Saetersdal, G. (1963). Selectivity of longlines. In: The selectivity of fishing gear. Spec. Publ. No. 5. [nt. Comm Northwest At]. Fish., Dartmouth, N.S., Canada, p $189-192$

Snedecor, W. G., Cochran, G. W. (1980). Statistical methods, 7 th edn. Iowa State Univ. Press, Ames

Tokai, T., Kitahara, I (1988). Methods of determining the mesh selectivity curve of trawlnet. Nippon Suisan Gakk. 55: 643-649

Tokai, T., Ito, H., Yamaguchi, Y (1989). A preliminary study on mesh selectivities small trawl nets to three flatfish species. Bull. Nansei Reg. Fish. Res. Lab. 22: 29-34

Underwood, A. J. (1981). Techniques of analysis of variance in experimental marine biology and ecology. Oceanogr mar. Biol. A. Rev. 19: 513-605

Underwood, A. J. (1990). Experiments in ecology and management: their logics, functions and interpretations. Aust. J. Ecol. 15: 365-389

Winer, B. J. (1971). Statistical principles in experimenta] design, 2nd edn., International student edition. McGraw-Hill Kogakusha Ltd, Tokyo

Manuscript first received: June 11, 1992

\author{
Revised version accepted: November 9, 1992
}

This article was presented by A. J. Underwood, Sydney,

Australia 